\title{
Importance of Screening Type-II Diabetics for Thyroid Dysfunction and Dyslipidemia
}

\author{
Peeyush Yadav ${ }^{1, *}$, G.G.Kaushik ${ }^{1}$, Sonali Sharma ${ }^{2}$ \\ ${ }^{1}$ Department of Biochemistry, J.L.N Medical College, India \\ ${ }^{2}$ Department of Biochemistry, R.U.H.S Medical College, India
}

Copyright (C) 2015 Horizon Research Publishing All rights reserved.

\begin{abstract}
OBJECTIVE: We aimed to evaluate association between thyroid dysfunction, lipid profile and glycated hemoglobin in type 2 diabetic patients. MATERIALS AND METHODS: The present study has been conducted on 100 diagnosed patients of Diabetes Mellitus Type - II and 100 healthy subjects of either sex of similar age group admitted or attending outpatient department of Jawahar Lal Nehru Hospital, Ajmer. Venous blood sample were withdrawn and assayed for thyroid function such as $\mathrm{FT}_{4}, \mathrm{FT}_{3}, \mathrm{~T}_{3}, \mathrm{~T}_{4}, \mathrm{TSH}$ and other biochemical investigation such as $\mathrm{FPG}, \mathrm{HbA}_{1 \mathrm{C}}$ and lipid profile. Statistical analysis was carried out using the Statistical Package for Social Sciences (SPSS 12.0 for windows). Independent $t$ test was used to compare quantitative data in groups. RESULTS: There is a marked Dyslipidemia with characteristic increase in the levels of Total Cholesterol, TG, VLDL-C, and LDL-C whereas the level of HDL-C decreases in Diabetic patients. Out of 100 Diabetic patients 34 have Thyroid Dysfunction out of which 26 have Hypothyroidism and 8 have Hyperthyroidism. The increase in the value of Serum Total Cholesterol, Triglyceride, LDL-C, VLDL-C and decrease in HDL $-\mathrm{C}$ level was observed statistically Highly Significant $(\mathrm{p}<0.0001)$ in Hypothyroid Diabetic subjects and Non - Significant $(\mathrm{p}=0.1072)$ in Hyperthyroid Diabetic subjects when compared with Euthyroid Diabetic subjects. CONCLUSION: Our study indicates that screening of thyroid dysfunction in type 2 diabetic patients is necessary because in Type 2 diabetics the prevalence of Hypothyroidism was higher with a significant increase in the levels of Total Cholesterol, Triglyceride and LDL - C while the levels of HDL $-\mathrm{C}$ decreases.
\end{abstract}

Keywords Type 2 diabetes mellitus, Thyroid dysfunction, Dyslipidemia

\section{Introduction}

Diabetes mellitus is a group of metabolic diseases characterized by hyperglycemia resulting from defects in insulin secretion, insulin action, or both [10]. Diabetes Mellitus the common heterogenous endocrine disorder is rising in India and has reached approximately $20 \%$ in urban population and approximately $10 \%$ in rural population [23]. Factors such as sedentary lifestyle, dietary modifications, ethnicity hypertension and obesity have led to a dramatic increase in the incidence of Diabetes Mellitus, especially in the 21st century [32].Thyroid disorders are also very common in the general population and it is second only to diabetes as the most common condition to affect the endocrine system. As a result it is common for an individual to be affected by both thyroid disease and diabetes. The first report showing the association between diabetes and Thyroid Dysfunction were published in 1979 [14]. Thyroid hormone action has long been recognized as an important determinant of glucose homeostasis [9]. Dyslipidemia is common in diabetes, as both insulin deficiency and insulin resistance affects enzymes and pathways of lipid metabolism.

Dyslipidemia is one of the major risk factors for cardiovascular disease in Diabetes Mellitus [21]. Diabetes has been shown to be associated with numerous thrombotic, atherosclerotic and cardiovascular diseases. Cholesterol has been pointed out as the cause of atherosclerosis. However, other lipids, such as triglycerides and phospholipids also show similar correlation [12]. As these studies do not fully explain the association of thyroid hormones and dyslipidemia in Type II Diabetes Mellitus subjects, it requires further study. Therefore, in the present study an attempt has been made to evaluate the role of thyroid hormone dysfunction and serum lipid levels in Type II Diabetics.

\section{Material \& Methods}

\section{Study Population :}

The present study has been conducted on 100 diagnosed patients of Diabetes Mellitus Type - II and 100 healthy subjects of either sex of similar age group admitted or attending outpatient department of Jawahar Lal Nehru Hospital, Ajmer. The criteria for diagnosis of Type 2 
diabetes were the American Diabetic Association criteria; FPG of $110 \mathrm{mg} / \mathrm{dl}$, random blood sugar of $200 \mathrm{mg} / \mathrm{dl}$ or taking hypoglycemic drugs and/or using insulin and did not have any episodes of ketosis in the past. Alcoholics, Pregnant ladies and patients with diseases that may affect thyroid function, were excluded. An informed verbal consent was taken from each and every patient.

\section{Biochemical Assessment}

Venous blood sample were withdrawn and assayed for thyroid function such as $\mathrm{FT}_{4}, \mathrm{FT}_{3}, \mathrm{~T}_{3}, \mathrm{~T}_{4}, \mathrm{TSH}$ and other biochemical investigation such as $\mathrm{FPG}, \mathrm{HbA}_{1 \mathrm{C}}$ and lipid profile. The serum levels of $\mathrm{FT}_{3}$ (normal range 1.5-4.2 pg $/ \mathrm{ml}$ ), $\mathrm{FT}_{4}$ (normal range $0.8-1.68 \mathrm{ng} / \mathrm{dl}$ ) were determined by using Enzyme Linked Immunosorbant Assay (ELISA) technique. $\mathrm{T}_{3}$ (normal range $70-210 \mathrm{ng} / \mathrm{dl}$ ), $\mathrm{T}_{4}$ (normal range 5.2-11.8 $\mu \mathrm{g} / \mathrm{dl}$ ) and TSH (normal range 0.2-5.2 $\mu \mathrm{iu} / \mathrm{ml}$ ) were determined by Radio Immuno Assay method. FPG (normal range $70-110 \mathrm{mg} / \mathrm{dl}$ ), $\mathrm{HbA}_{1} \mathrm{c}$ (normal range 4.2-6.2\%), serum cholesterol (normal range150-200 $\mathrm{mg} / \mathrm{dl}$ ), serum triglycerides (normal range 100-150 mg/dl), serum HDL (normal range $35-48 \mathrm{mg} / \mathrm{dl}$ ), serum LDL (normal range $<130$ ), serum VLDL (normal range $5-35 \mathrm{mg} / \mathrm{dl}$ ), were determined on semi-automated clinical chemistry analyzer.

\section{Statistical Analysis}

Statistical analysis was carried out using the Statistical Package for Social Sciences (SPSS 12.0 for windows). Independent $\mathrm{t}$ test was used to compare quantitative data in groups. Pearson correlation coefficient was used to determine the correlation between quantitative data. $\mathrm{P}$ value $<0.05$ was considered significant.

\section{Results}

Anthropometric and biochemical characteristics of the studied population are presented in Table 1 . There is a marked Dyslipidemia with characteristic increase in the levels of Total Cholesterol, TG, VLDL-C, and LDL-C whereas the level of HDL-C decreases in Diabetic patients.

Table 1. Anthropometric and Biochemical Characteristics of The Studied Population

\begin{tabular}{|c|c|c|}
\hline Parameters & $\begin{array}{c}\text { Non-Diabetic } \\
\text { Subjects }\end{array}$ & $\begin{array}{l}\text { Diabetic } \\
\text { Subjects }\end{array}$ \\
\hline Age (in years) & $45 \pm 8$ & $52 \pm 10$ \\
\hline Height (in cms) & $160 \pm 10$ & $156 \pm 9$ \\
\hline Weight (in Kg.) & $65 \pm 5$ & $59 \pm 6$ \\
\hline BMI (in $\mathrm{Kg} / \mathrm{m}^{2}$ ) & $24 \pm 2$ & $28 \pm 3.5$ \\
\hline Blood glucose $(\mathrm{F})(\mathrm{mg} / \mathrm{dl})$ & $88.73 \pm 12.1$ & $164.6 \pm 15.4$ \\
\hline $\mathrm{HbA}_{1 \mathrm{c}}(\%$ age $)$ & $4.9 \pm 1.1$ & $9.2 \pm 1.8$ \\
\hline $\mathrm{T}_{3}(\mathrm{ng} / \mathrm{ml})$ & $1.1 \pm 0.20$ & $0.82 \pm 0.15$ \\
\hline $\mathrm{T}_{4}(\mu \mathrm{g} / \mathrm{dl})$ & $8.7 \pm 1.8$ & $6.85 \pm 1.9$ \\
\hline $\mathrm{FT}_{3}(\mathrm{pg} / \mathrm{ml})$ & $2.86 \pm 1.0$ & $2.2 \pm 0.6$ \\
\hline $\mathrm{FT}_{4}(\mathrm{ng} / \mathrm{ml})$ & $1.2 \pm 0.24$ & $0.9 \pm 0.2$ \\
\hline $\mathrm{TSH}(\mu \mathrm{IU} / \mathrm{ml})$ & $2.5 \pm 0.87$ & $5.62 \pm 1.1$ \\
\hline Total Cholesterol(mg/dl) & $145.30 \pm 20.0$ & $197.2 \pm 28.2$ \\
\hline Triglyceride(mg/dl) & $125.25 \pm 9.0$ & $172.1 \pm 17.30$ \\
\hline $\mathrm{HDL}-\mathrm{C}(\mathrm{mg} / \mathrm{dl})$ & $40.1 \pm 8.2$ & $32.0 \pm 12.0$ \\
\hline $\mathrm{VLDL}-\mathrm{C}(\mathrm{mg} / \mathrm{dl})$ & $25.0 \pm 2.0$ & $34.42 \pm 4.0$ \\
\hline $\mathrm{LDL}-\mathrm{C}(\mathrm{mg} / \mathrm{dl})$ & $80.15 \pm 15.1$ & $130.78 \pm 30.0$ \\
\hline
\end{tabular}

The study shows that out of 100 Diabetic patients 34 have Thyroid Dysfunction out of which 26 have Hypothyroidism and 8 have Hyperthyroidism. (Table 2).

Table 2. Comparison of Non - Diabetic and Diabetic Subjects With Raised, Low and Normal Thyroid Hormone $\left(\mathrm{T}_{3}, \mathrm{~T}_{4}, \mathrm{FT}_{3}, \mathrm{FT}_{4}\right) \mathrm{Levels}_{\text {. }}$

\begin{tabular}{|c|c|c|c|c|c|c|}
\hline \multirow{2}{*}{ Subjects } & \multicolumn{2}{|c|}{ Non-Diabetic Subjects $(\mathrm{n}=100)$} & \multicolumn{3}{c|}{ Diabetic Subjects $(\mathrm{n}=100)$} \\
\cline { 2 - 7 } & Total Subjects & Male & Female & Total Subjects & Male & Female \\
\hline $\begin{array}{c}\text { Normal levels } \\
\text { (Euthyroid) }\end{array}$ & 92 & 45 & 47 & 66 & 34 & 32 \\
\hline $\begin{array}{c}\text { Low levels } \\
\text { (Hypothyroid) }\end{array}$ & 5 & 4 & 1 & 26 & 11 & 15 \\
\hline $\begin{array}{c}\text { Raised levels } \\
\text { (Hyperthyroid) }\end{array}$ & 3 & 1 & 2 & 8 & 5 & 3 \\
\hline
\end{tabular}

The increase in the value of Serum Total Cholesterol, Triglyceride, LDL-C, VLDL-C and decrease in HDL -C level was observed statistically Highly Significant $(\mathrm{p}<0.0001)$ in Hypothyroid Diabetic subjects (Table 3, Fig.1) and Non - Significant $(\mathrm{p}=0.1072)$ in Hyperthyroid Diabetic subjects (Table 4, Fig.2) when compared with Euthyroid Diabetic subjects.

Table 3. Comparison of Serum Lipid Profile Levels of Euthyroid and Hypothyroid Diabetic Subjects.

\begin{tabular}{|c|c|c|c|}
\hline Parameters & Euthyroid Subjects $(\mathrm{n}=66)$ & Hypothyroid Subjects $(\mathrm{n}=26)$ & P- value* \\
\hline Total Cholesterol $(\mathrm{mg} / \mathrm{dl})$ & $162.0 \pm 10.0$ & $204.0 \pm 12.0$ & $<0.0001$ (HS) \\
\hline Triglyceride $(\mathrm{mg} / \mathrm{dl})$ & $135.0 \pm 15.0$ & $180.0 \pm 9.0$ & $<0.0001(\mathrm{HS})$ \\
\hline HDL $-\mathrm{C}(\mathrm{mg} / \mathrm{dl})$ & $36.0 \pm 4.0$ & $29.0 \pm 3.0$ & $<0.0001(\mathrm{HS})$ \\
\hline VLDL $-\mathrm{C}(\mathrm{mg} / \mathrm{dl})$ & $27.0 \pm 3.0$ & $36.0 \pm 1.8$ & $<0.0001(\mathrm{HS})$ \\
\hline LDL $-\mathrm{C}(\mathrm{mg} / \mathrm{dl})$ & $103.0 \pm 10.0$ & $139.0 \pm 11.0$ & $<0.0001(\mathrm{HS})$ \\
\hline
\end{tabular}




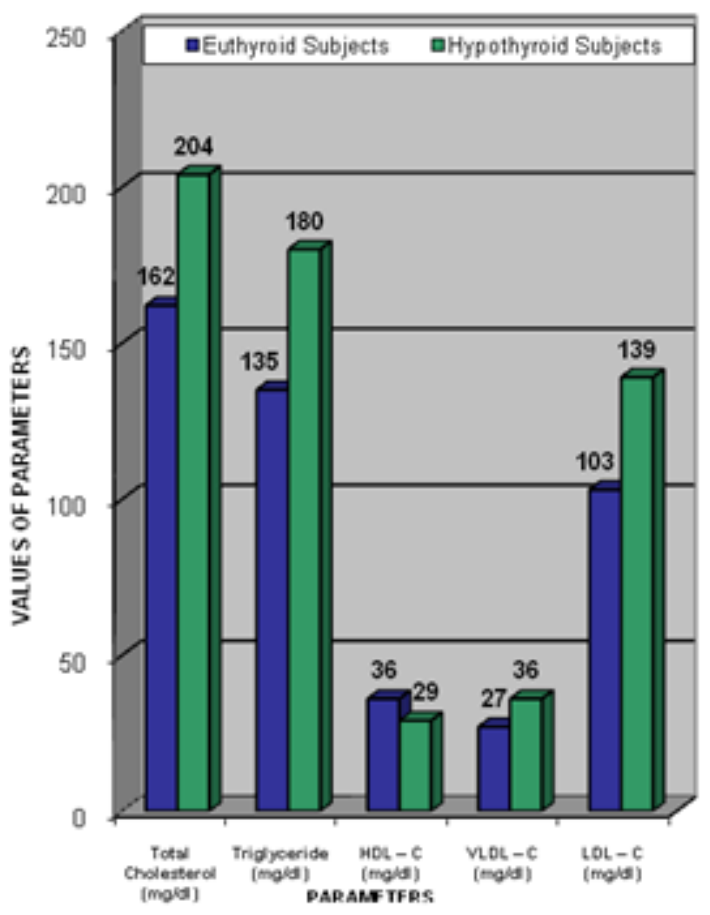

Figure 1. Comparison of Serum Lipid Profile Levels of Euthyroid and Hypothyroid Diabetic Subjects.

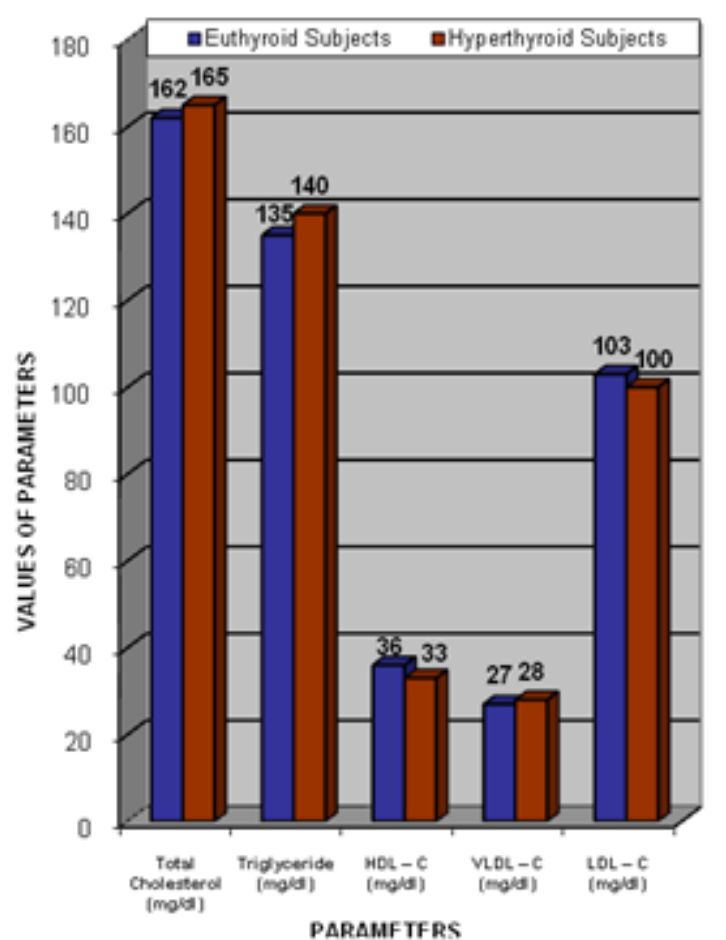

Figure 2. Comparison of Serum Lipid Profile Levels of Euthyroid And Hyperthyroid Diabetic Subjects.

Table 4. Comparison of Serum Lipid Profile Levels of Euthyroid and Hyperthyroid Diabetic Subjects.

\begin{tabular}{|c|c|c|c|}
\hline Parameters & Euthyroid Subjects $(\mathrm{n}=66)$ & Hyperthyroid Subjects $(\mathrm{n}=8)$ & P- value* \\
\hline Total Cholesterol (mg/dl) & $162.0 \pm 10.0$ & $165.0 \pm 9.0$ & 0.4213 (NS) \\
\hline Triglyceride (mg/dl) & $135.0 \pm 15.0$ & $140.0 \pm 10.0$ & 0.2113 (NS) \\
\hline HDL $-\mathrm{C}(\mathrm{mg} / \mathrm{dl})$ & $36.0 \pm 4.0$ & $33.0 \pm 5.0$ & 0.1072 (NS) \\
\hline VLDL $-\mathrm{C}(\mathrm{mg} / \mathrm{dl})$ & $27.0 \pm 3.0$ & $28.0 \pm 2.0$ & 0.363 (NS) \\
\hline LDL $-\mathrm{C}(\mathrm{mg} / \mathrm{dl})$ & $103.0 \pm 10.0$ & $100.0 \pm 8.0$ & 0.4173 (NS) \\
\hline
\end{tabular}

Comparison of Hypoythyroid Diabetic subjects with Hyperthyroid Diabetic subjects shows that the increase in the value of Serum Total Cholesterol, Triglyceride,LDL-C, VLDL-C and decrease in HDL-C level is statistically Significant ( $p=0.0086$ ).

Table 5. Comparison of Serum Lipid Profile Levels of Hypothyroid and Hyperthyroid Diabetic Subjects.

\begin{tabular}{|c|c|c|c|}
\hline Parameters & $\begin{array}{c}\text { Hypothyroid Subjects } \\
(\mathrm{n}=26)\end{array}$ & Hyperthyroid Subjects $(\mathrm{n}=8)$ & P- value* \\
\hline Total Cholesterol (mg/dl) & $204.0 \pm 12.0$ & $165.0 \pm 9.0$ & $<0.0001(\mathrm{HS})$ \\
\hline Triglyceride $(\mathrm{mg} / \mathrm{dl})$ & $180.0 \pm 9.0$ & $140.0 \pm 10.0$ & $<0.0001(\mathrm{HS})$ \\
\hline $\mathrm{HDL}-\mathrm{C}(\mathrm{mg} / \mathrm{dl})$ & $29.0 \pm 3.0$ & $33.0 \pm 5.0$ & $0.0086(\mathrm{~S})$ \\
\hline $\mathrm{VLDL}-\mathrm{C}(\mathrm{mg} / \mathrm{dl})$ & $36.0 \pm 1.8$ & $28.0 \pm 2.0$ & $<0.0001(\mathrm{HS})$ \\
\hline $\mathrm{LDL}-\mathrm{C}(\mathrm{mg} / \mathrm{dl})$ & $139.0 \pm 11.0$ & $100.0 \pm 8.0$ & $<0.0001(\mathrm{HS})$ \\
\hline
\end{tabular}




\section{Discussion}

India has the dubious distinction of being home to the largest number of people suffering from diabetes in any country [22]. Glucose fluctuations occur all the time. One way to assess the mean levels is to monitor the $\mathrm{HbA}_{1 \mathrm{C}}$, which gives the average blood glucose level of the preceding 2-3 months. In uncontrolled or poorly controlled diabetes there is an increased glycosylation of a number of proteins, including hemoglobin. $\mathrm{HbA}_{1 \mathrm{C}}$ was found to increase in patients with diabetes to approximately $16 \%$, and the amount of increase was directly proportional to the fasting blood glucose level [22]. During diabetes, the excess glucose present in blood reacts with hemoglobin $[13,25]$. In the present study, we noticed a marked increase in $\mathrm{HbA}_{1 \mathrm{C}}$ levels in diabetic patients, which could be due to excessive glycosylation of hemoglobin. The chronic hyperglycemia of diabetes is associated with long term damage, dysfunction and failure of various organs, especially the eyes, kidneys, nerves, heart, liver, blood vessels and other endocrine organs.

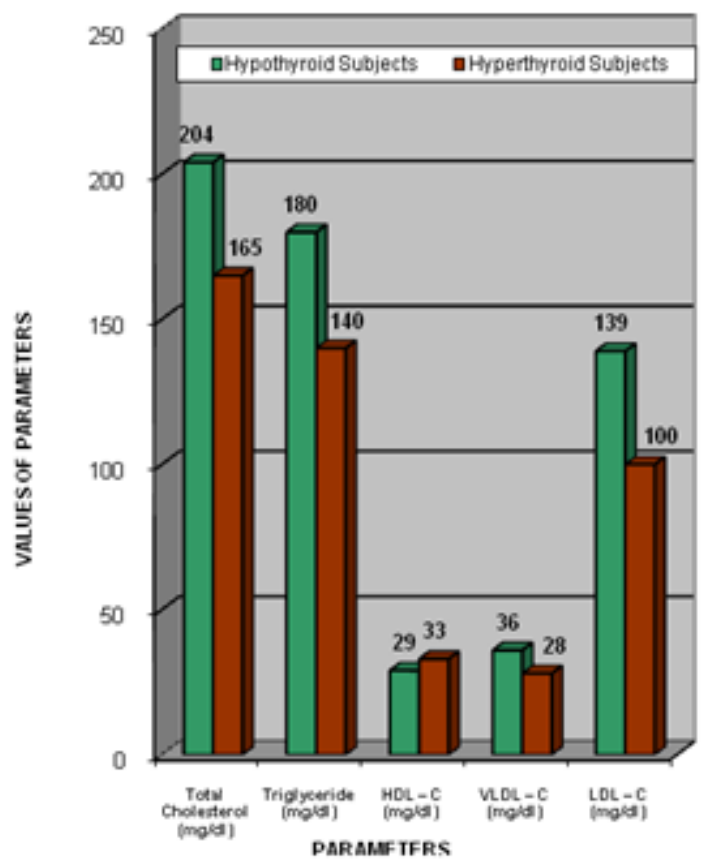

Figure 3. Comparison of Serum Lipid Profile Levels of Hypothyroid And Hyperthyroid Diabetic Subjects

In this study diabetic subjects show significant higher serum levels of cholesterol, triglycerides, LDL, VLDL and lower level of HDL as compared to non diabetic subjects. The abnormally high concentration of serum lipid in diabetes is mainly due to the increase in mobilization of free fatty acids from peripheral fat depots [3]. The precise pathogenesis of diabetic dyslipidemia is not known; nevertheless, a large body of evidence suggests that insulin resistance has a central role in the development of this condition $[6,8,18,30]$. The main cause of the three cardinal features of diabetic dyslipidemia is the increased free fatty-acid release from insulin-resistant fat cells. The increased flux of free fatty acids into the liver in the presence of adequate glycogen stores promotes triglyceride production, which in turn stimulates the secretion of apolipoprotein B (ApoB) and VLDL cholesterol. The impaired ability of insulin to inhibit free fatty-acid release leads to enhanced hepatic VLDL cholesterol production [11], which correlates with the degree of hepatic fat accumulation [1]. The increased number of VLDL cholesterol particles and increased plasma triglyceride levels decrease the level of HDL cholesterol and increase the concentration of small dense LDL- cholesterol particles via several processes: VLDL- transported triglyceride is exchanged for HDLtransported cholesteryl ester through the action of the cholesteryl ester transfer protein (CETP), which results in increased amounts of both atherogenic cholesterol-rich VLDL remnant particles and triglyceride-rich, cholesterol-depleted HDL particles. The triglyceride -enriched HDL is subsequently hydrolyzed by hepatic lipase or lipoprotein lipase; ApoA-I dissociates from the reduced-size HDL, which is filtered by the renal glomeruli and degraded in renal tubular cells $[19,20]$. The increased concentration of small dense LDL-cholesterol particles is explained by a similar lipid exchange. Increased levels of VLDL-transported triglyceride enable CETP to promote the transfer of triglyceride into LDL in exchange for LDL-transported cholesteryl ester. The triglyceride-rich LDL undergoes hydrolysis by hepatic lipase or lipoprotein lipase, which results in lipid-depleted small dense LDL particles. Our results are in consistence with previous cross sectional study conducted among young adult population by Sawant et al., [26] where increase prevalence of dyslipidemia was found to be the major contributor of CVD.

The present study reported high incidence of abnormal thyroid hormone level in type 2 diabetic population. Our observation is in agreement with reports of Suzuki et al,; Celani et al [4], and Udiong et al [5], who in separate studies found altered thyroid hormone level of different magnitude in diabetic patients. The present study reveals different grades of thyroid dysfunction among diabetes. Hypothyroidism is present in $26 \%$ and hyperthyroidism is present in $8 \%$ of diabetic subjects. This goes in accordance with the reports of Suzuki et al,[29] and Smithson et al,[28] who in separate studies found altered thyroid hormone level of different magnitude (both low and high) in diabetic patient. The abnormal thyroid hormone level may be the outcome of various medications the diabetic was receiving. For example, it is known that insulin [2], an anabolic hormone enhances the level of $\mathrm{FT}_{4}$ while it suppresses the level of $\mathrm{T}_{3}$ by inhibiting hepatic conversion of $\mathrm{T}_{4}$ to $\mathrm{T}_{3}$. On the other hand some of the oral hypoglycemic agents such as the phenylthioureas are known to suppress the level of $\mathrm{FT}_{4}$ and $\mathrm{T}_{4}$, while causing raised levels of TSH [27,31]. Some of the type 2 diabetic was on oral hypoglycemic agents alone and some were on both insulin injections and oral hypoglycemic agents. These situations may explain the finding of low or raised thyroid hormones levels in some of the euthyroid 
diabetics. The presence of both raised and low levels of thyroid hormones levels in diabetics in this study may also be due to modified thyroid releasing hormone (TRH)s synthesis and release [7] and may depend on the glycaemic status of the diabetics studied. Glycaemic status is influenced by insulin, which is known to modulate TRH and TSH levels [24]. Insulin, which is used in treating diabetes and is produced in normal quantities or in excess, has been associated with increased anabolic activity [17]. Recently, C-peptide has also been shown to enhance $\mathrm{Na}+/ \mathrm{K}+-$ ATPase activity, an action that may also increase protein synthesis. Such an action would induce increased turnover of TSH, a protein hormone [5]. The bulk of the hormones secreted by follicular cells of the thyroid gland are released in the free form into plasma where they become largely bound to thyroid binding globulin (TBG) and to some extent to pre-albumin and albumin. A small fraction circulates free in plasma( $\mathrm{FT}_{3}$ and $\left.\mathrm{FT}_{4}\right)$ Suzuki et al. [29] attributed the abnormal thyroid hormone levels found in diabetes to the presence of thyroid hormone binding inhibitor (THBI), an inhibitor of the extra thyroidal conversion enzyme (5'-deiodinase) of $\mathrm{T}_{4}$ to $\mathrm{T}_{3}$, and dysfunction of the hypothalamo - pituitary - thyroid axis. These situations may prevail in diabetes and would be aggravated in poorly controlled diabetics.

As Johnson et al. said, "The thyroid hormones, tri-iodothyronine and tetra- iodothyronine, are insulin antagonists that also potentiate the action of insulin indirectly." [16].TRH synthesis decreases in diabetes, and this could be responsible for the occurrence of low thyroid hormone levels in diabetics.[28] In our study, the TSH was significantly higher in diabetics than in non-diabetics $(5.62 \pm$ $1.1: \mu \mathrm{IU} / \mathrm{mL}$ vs $2.52 \pm 0.87: \mu \mathrm{IU} / \mathrm{mL}, \mathrm{p}<0.0001)$.

Elevations in total cholesterol and low-density lipoprotein cholesterol (LDL-C) may occur in hypothyroidism due to several changes in the synthesis, metabolism, and mobilization of lipids. Thyroid hormone induces the hepatic expression of hydroxymethylglutaryl coenzyme A reductase, which results in increased cholesterol synthesis [33]. Therefore, in overt hypothyroidism, hepatic cholesterol synthesis is decreased. However, thyroid hormone also increases the expression of cell surface LDL-C receptors expressed in fibroblasts, liver, and other tissues. LDL-C receptor levels are regulated by negative feedback in the presence of high intracellular cholesterol levels. This may be mediated through the sterol regulatory element-binding protein-2 (SREBP-2). The SREBP-2 gene is directly regulated by T3 [34]. The decrease in LDL-C receptors leads to reduced clearance of LDL-C from the serum. Hypothyroidism may also lead to increased intestinal cholesterol absorption due to thyroid hormone actions on Niemann-Pick C1-like 1 protein in the gut [35]. The thyroid hormone effects on LDL-C receptor expression and cholesterol absorption outweigh the effects of decreased hepatic cholesterol synthesis, leading to a net accumulation of serum LDL-C in overt hypothyroidism. Although the overall effects of subclinical hypothyroidism on serum lipid levels remain unclear, it is likely that more subtle manifestations of the same alterations that occur in overt hypothyroidism are present in mildly hypothyroid patients.

Cholesteryl ester transfer protein (CETP) transfers cholesterol from high-density lipoprotein cholesterol (HDL-C) to LDL-C and very low density lipoprotein (VLDL). Plasma CETP concentrations are decreased in hypothyroidism and increased in hyperthyroidism, which may lead to alterations in serum HDL-C concentrations [36]. Thyroid hormone also appears to play a role in the regulation of hepatic lipase, which alters HDL-C subfractions [36]. In addition, thyroid hormone stimulates cholesterol efflux from macrophages to HDL via the ABCA1 transporter [37].

Lipoprotein lipase lowers triglyceride levels through hydrolysis of triglyceride-enriched lipoproteins and facilitates transfer of cholesterol from these lipoproteins to HDL-C. Lipoprotein lipase activity is increased by thyroid hormone. Higher serum triglycerides may be observed in overtly hypothyroid individuals because of their lower lipoprotein lipase activity [38].

The type 2 diabetic subjects with thyroid dysfunction tended to have higher levels of blood lipids and $\mathrm{HbA}_{1 \mathrm{C}}$ compared with those of control. This confirms that thyroid hormones affect on blood glucose as well as lipid levels.

\section{Conclusions}

Our study indicates that in Type 2 Diabetes mellitus subjects, insulin resistance has a central role in the development of diabetic dyslipidemia. Type 2 Diabetes mellitus subjects were more prone to have Thyroid Dysfunction and the prevalence of Hypothyroidism was higher with a significant increase in the levels of Total Cholesterol, Triglyceride and LDL - C while the levels of $\mathrm{HDL}-\mathrm{C}$ decreases. So, screening of thyroid dysfunction in type 2 diabetic patients is necessary because it can produce significant metabolic disturbances.

\section{REFERENCES}

[1] Adiels $\mathrm{M}$ et al. Acute suppression of VLDL1 secretion rate by insulin is associated with hepatic fat content and insulin resistance. Diabetologia (2007) 50: 2356-2365

[2] Boehringer Mannheim. Extrathyroidal factor affecting thyroid hormone concentration. Rational approach to thyroid diagnosis, Gmbh, Boehringer Mannheim. (1984). pp 2-4

[3] Bopama, K.N., Kanna,J., Sushma,G., Balaraman,R. and Rathod,S.P.. Antidiabetic and antihyperlipidemic effects of neem seed kernel powder on alloxan diabetic rabbits. Ind. J. Pharmacol. (1997) 29: 162-167.

[4] Celani ,M.F., Bonati, M.E. and Stucci, N.. Prevalence of abnormal thyrotropin concentrations measured by a sensitive 
assay in patients with Type 2 diabetes mellitus. Diabete Res. (1994) 27(1):15-25.

[5] C. E.J. Udiong, A. E. Udoh and M. E. Etukudoh : Evaluation of thyroid function in diabetes mellitus in calabar, Nigeria. Indian Journal of Clinical Biochemistry (2007); 22 (2) 74-78.

[6] Chahil TJ and Ginsberg HN. Diabetic dyslipidemia. Endocrinol Metab Clin North Am (2006) 35: 491-510

[7] De-Greef, W.J., Rondeel, J.M. and Van-Haasteren, G.A., Klootwij, K.W., Visser, T.J.. Regulation of TRH production and release in rats. Acta Medica Austriaca. (1992) 19(Suppl 1): 77-9

[8] Del Pilar Solano M and Goldberg RB Management of diabetic dyslipidemia. Endocrinol Metab Clin North Am (2005) 34: 1-25

[9] Dimitriadis, G. and Raptis, S.A.: Thyroid hormone excess and glucose intolerance. Exp. Clin. Endocrinol. (2001); Diabetes, 109: S225-S239.

[10] Donath MY and Ehses JA : Type 1, type 1.5 and Type 2 Diabetes: NOD the diabetes we thought it was. Proc Natl Acad Sci USA (2006) August 15; 103(33):12217-12218.

[11] Frayn KN. Adipose tissue and the insulin resistance syndrome. Proc Nutr Soc (2001) 60: 375-380

[12] Fumelli P., Romagnoli F., Carlino G., Fumelli C. and Boemi M.: Diabetes mellitus and chronic heart failure. Arch. Gerontol. Geriatr. (1996); 23:277-281.

[13] Gloria-Botthini, F., Antonacci, E., Bottini, N., Ogana, A., Borgiani, P., De Santis, G., and Lucarini, N.: Rh blood groups and diabetic disorders: Is there an effect on glycosylated hemoglobin level. Hum. Biol., (2000) 72: 287-294.

[14] Gray RS, Irvine WJ, Clarke BF: Screening for Thyroid Dysfunction in diabetics. Br Med J. (1979) Dec 1; 2(6202):1439.

[15] Jennal L. Johnson. : Diabetes Control in Thyroid Disease Diabetes Spectrum. (2006), Volume 19, Number 3, 148-153.

[16] Johnson, J.L. and Duick, D.S.: Diabetes and thyroid disease: A likely combination. Diabetes Spectrum, (2002) 15:140-142.

[17] Khandekar, S.: Therapy related weight gain among non-insulin dependent diabetics in Saudi Arabia. Pract. Diabetes Digest. (1991), 2:84-86.

[18] Krauss RM and Siri PW. Dyslipidemia in type 2 diabetes. Med Clin North Am (2004) 88: 897-909

[19] Mooradian AD et al. Low serum high-density lipoprotein cholesterol in obese subjects with normal serum triglycerides: the role of insulin resistance and inflammatory cytokines. Diabetes Obes Metab (2007) 9: 441-443

[20] Mooradian AD et al. Obesity-related changes in high density lipoprotein metabolism. Obesity (2008) 16: 1152-1160

[21] Niemeijer - Kanters SD, Banga JD, Erkelens DW: Dyslipidemia in diabetes mellitus. Ned Tijdschr Geneeskd (2001) Apr 21; 145(16): 769 - 74.

[22] Palanisamy Pasupathi, Govindaswamy Bakthavathsalam,
Ganesan Saravanan, Ramachandran Sundaramoorthi: Screening for Thyroid Dysfunction in the Diabetic / Non-Diabetic Population. Thyroid Science (2008); 3(8):1-6.

[23] Ramachandran A, Snehalatha C: Current scenario of diabetes in India. J Diabetes. (2009) Mar; 1 (1):18-28.

[24] Reusch,C.E. and Tomsa,K. Serum fructosamine concentration in cats with overt hyperthyroidism. J American Vet Med Asso (1999) 215(9): 1297-330.

[25] Sampson, M.J., Hughes, D.A., Carrier, M.J., and Davies, I.R.: Status of HbA1C during acute hyperglycemia in type 2 diabetes. Diabetes Care, (2002) 25:537-541.

[26] Sawant,A.M., Shetty,D., Mankeshwar,R. and Ashavaid,T.F. Prevalence of Dyslipidemia in Young Adult Indian Population. JAPI (2008).Vol.56. 99-102.

[27] Smith, A.F., Becket, G.J., Walker, S.W. and Rae, P.W.H.. Abnormalities of thyroid function. Lecture Notes on Clinical Chemistry. Sixth edition. Oxford: Black-well Science Ltd. (1998) pp 91-104.

[28] Smithson, M.J. Screening for thyroid dysfunction in a community population of diabetic patients. Diabet Med. (1998)15 (2):148-150.

[29] Suzuki, J., Nanno, M., Gemma, R., Tanaka, I., Taminato, T., and Yoshimi, T.: The mechanism of thyroid hormone abnormalities in patients with diabetes mellitus. Nippon Niabunpi. Gakki. Zasshi., (1994) 7:465-470.

[30] Taskinen MR. Diabetic dyslipidaemia: from basic research to clinical practice. Diabetologia (2003) 46: 733-749.

[31] Whitley, R.J. Thyroid functions. In Burtis C, Ashwood AR. editors. Teitz text book of Clinical Chemistry, 3rd Edition. Philadelphia: Saunders \& Company. (1984) pp 1496-529.

[32] Wild, S., Roglic, G., Green, A., Sicree, R. and King, H: Global prevalence of diabetes. Diabetes Care. (2004); 27:1047- 1053 .

[33] Choi JW , Choi HS: The regulatory effects of thyroid hormone on the activity of 3-hydroxy-3-methylglutaryl coenzyme A reductase. Endocr (2000); Res 26:1-21.

[34] Shin DJ , Osborne TF. Thyroid regulation and cholesterol metabolism are connected through sterol regulatory element-binding protein-2 (SREBP-2). J Biol Chem (2003); 278:34114-34118.

[35] Gälman C, Bonde Y, Matasconi M, Angelin B, Rudling M. Dramatically increased intestinal absorption of cholesterol following hypophysectomy is normalized by thyroid hormone. Gastroenterology (2008) 134:1127-1136.

[36] Tan KC, Shiu SW, Kung AW. Plasma cholesteryl ester transfer protein activity in hyper- and hypothyroidism. J Clin Endocrinol Metab (1998); 83:140-143

[37] Boone LR, Lagor WR, Moya Mde L, Niesen MI, Rothblat GH, Ness GC. Thyroid hormone enhances the ability of serum to accept cellular cholesterol via the ABCA1transporter. Atherosclerosis(2011); 218:77-82.

[38] Lam KS , Chan MK, Yeung RT. High-density lipoprotein cholesterol, hepatic lipase and lipoprotein lipase activities in thyroid dysfunction - effects of treatment. Q J Med (1986); 59:513-521. 